Journal of Animal and Veterinary Advances 10 (19): 2550-2556, 2011

ISSN: $1680-5593$

(C) Medwell Journals, 2011

\title{
The Effects of Outdoor Housing and Cafeteria Feeding on Growth Performance and Feeding Behaviour of Awassi Lambs Kept in Hot Climate Condition
}

\author{
Serafettin Kaya \\ Department of Animal Sciences, Faculty of Agriculture, Mustafa Kemal University, \\ 31034 Antakya, Hatay, Turkey
}

\begin{abstract}
Study was carried out to determine the effects of shade allowance and cafeteria feeding on feeding behaviour of Awassi lambs kept in hot climate condition. The two housing methods indoor and outdoor and two feeding methods (single and cafeteria feeding) were tested (ISF, OSF, ICF and OCF). The thirty two lambs 3 months old male were divided into four groups and housed individually for 42 days. Results showed that daily gain, feed efficiency, the intake of water, protein, energy and fibre, the selection of energy, protein and fibre and water/feed ratio were affected by treatments $(\mathrm{p}<0.05$ ). Indoor lambs, made a diet containing $29.27 \% \mathrm{~B}, 27.10 \%$ $\mathrm{C}, 11.63 \% \mathrm{CSM}, 3.30 \% \mathrm{FFS}, 19.17 \% \mathrm{~A}$ and $9.52 \% \mathrm{WB}$ while outdoor ones made a diet having $24.75 \%$ $\mathrm{B}, 27.12 \mathrm{C}, 9.60 \% \mathrm{CSM}, 9.22 \% \mathrm{FFS}, 16.12 \% \mathrm{~A}$ and $13.20 \% \mathrm{WB}$. Eating, drinking and standing were significant at $(p>0.05)$ while ruminating and lying were significant at $(\mathrm{p}<0.001)$ respective groups ISF, OSF, ICF and OCF. In conclusion, single fed Awassi lambs kept in outdoor in hot climate showed less ruminating but more lying behaviour while given opportunity to choose a diet they ate more concentrate feed ingredients such as full fat soya and wheat bran without changing their behaviour patterns. Cafeteria feeding in lambs allows physiological arrangements against heat stress in outdoor housing condition by dietary self selection and by tuning respiratory and circulatory systems.
\end{abstract}

Key words: Awassi lambs, housing method, heat stress, behaviour, cafeteria feeding, opportunity

\section{INTRODUCTION}

High ambient temperature with high direct and indirect solar radiation, wind speed and relative humidity cause the effective temperature of the environment to often exceed the thermo neutral zone of the animals $\left(5-25^{\circ} \mathrm{C}\right.$; McDowell, 1972), leading the heat stress (Bianca, 1962; Finch, 1984; Hayes et al., 2003). The effect of heat stress is also substantial in the subtropical-mediterranean zones and farm animals raised in this area are exposed annually for 3-5 months to considerable heat stress (Silanikove, 1992). The best recognized effect of raised body temperature is an adaptive depression of the metabolic rate associated with reduced appetite (Silanikove, 2000). There is a clear evidence that animals subjected to prolonged periods heat stress significantly reduce their dry matter intake (Thwaites, 1967; Abdel-Samee and Diel, 1998; Holst and Stanley, 2000; Beatty et al., 2006) and consequently, results in a fall in performance. Intake depression can be exacerbated by the consumption of diets containing a high percentage of roughage (Brink, 1975; Dixon et al., 1999).

Animals can successfully select a diet to meet their physiological and nutritional needs (Rose and Kyriazakis,
1991; Forbes, 1995; Sahin et al., 2001) to meet their nutritional requirements (Kyriazakis and Oldham, 1993; Arsenos and Kyriazakis, 1999). Recently, Gorgulu et al. (1996), Sahin et al. (2003) and Keskinet al. (2004) reported that Awassi lambs raised under a cafeteria feeding system successfully selected the diet to match their nutritional requirements and showed a performance similar to lambs raised under a conventional feeding system. However, the previous researcher have not been study enough the effect of environmental condition to diet choice in small ruminants.

There has been a limited study regarding the effect of environmental factors on behavioural and physiological responses of small ruminants. Previous feeding behaviour studies had been carried out in grazing conditions. However, it was not known how animals change their behavioural and physiological responses when given to live in house absolutely protected from sunshine in hot climate and also allowed to make their own diets from offered feed ingredients in these environmental conditions. Therefore, the current study was conducted to determine the effects of housing method and cafeteria feeding on growth performance and feeding behaviour of Awassi lambs kept in hot climate condition. 
Table 1: The nutrient composition of single diet

\begin{tabular}{|c|c|}
\hline Ingredients & Percentage \\
\hline $\begin{array}{l}\text { Barley ( } 890 \mathrm{~g} \mathrm{DM}, 2900 \mathrm{kcal} \mathrm{ME}, \\
\left.110 \mathrm{~g} \mathrm{CP} \text { and } 52 \mathrm{~g} \mathrm{CF} \mathrm{kg}^{-1}\right)\end{array}$ & 40.00 \\
\hline $\begin{array}{l}\text { Com }\left(890 \mathrm{~g} \mathrm{DM}, 3000 \mathrm{kcal} \mathrm{ME}^{-1}\right. \\
\left.90 \mathrm{~g} \mathrm{CP} \text { and } 28.5 \mathrm{~g} \mathrm{CF} \mathrm{kg}^{-1}\right)\end{array}$ & 5.00 \\
\hline $\begin{array}{l}\text { Wheat bran }\left(890 \mathrm{~g} \mathrm{DM}^{2} 200 \mathrm{kcal} \mathrm{ME} \text {, }\right. \\
\left.180 \mathrm{~g} \mathrm{CP} \text { and } 110 \mathrm{~g} \mathrm{CF} \mathrm{kg}^{-1}\right)\end{array}$ & 25.00 \\
\hline $\begin{array}{l}\text { Cotton seed meal }(900 \mathrm{~g} \mathrm{DM}, 2100 \mathrm{kcal} \mathrm{ME} \text {, } \\
\left.290 \mathrm{~g} \mathrm{CP}^{-1} 190 \mathrm{~g} \mathrm{CF} \mathrm{kg}^{-1}\right)\end{array}$ & 9.00 \\
\hline $\begin{array}{l}\text { Full-fat soybean }\left(900 \mathrm{~g} \mathrm{DM}^{-}, 3200 \mathrm{kcal} \mathrm{ME} \text {, }\right. \\
\left.380 \mathrm{~g} \mathrm{CP} \text { and } 50 \mathrm{~g} \mathrm{CF} \mathrm{kg}^{-1}\right)\end{array}$ & 9.00 \\
\hline $\begin{array}{l}\text { Alfalfa straw }(870 \mathrm{~g} \mathrm{DM} 1800 \mathrm{kcal} \mathrm{ME} \text {, } \\
\left.142 \mathrm{~g} \mathrm{CP} \text { and } 190 \mathrm{~g} \mathrm{CF} \mathrm{kg}^{-1}\right)\end{array}$ & 10.00 \\
\hline $\begin{array}{l}\text { Vitamin and mineral mixture } \\
\text { (obtained from commercial source) }\end{array}$ & 2.00 \\
\hline Calculated composition per $\mathrm{kg}$ fresh diet & 251700 \\
\hline Dry Matter (DM) (g) & 872.00 \\
\hline Crude Protein (CP) (g) & 168.00 \\
\hline Crude Fiber $(\mathrm{CF})(\mathrm{g})$ & 90.32 \\
\hline
\end{tabular}

\section{MATERIALS AND METHODS}

The thirty two 3 months old fat-tailed male Awassi lambs were used in this study at the Research Farm of Mustafa Kemal University, Antakya province, Turkey. Antakya is located between $36^{\circ} \mathrm{N}$ latitude and $36^{\circ} \mathrm{E}$ longitude in the Eastern mediterranean region where climatic conditions are hot and dry in summer and warm and rainy in winter.

At the beginning of the study, the lambs $(n=32)$ were numbered with ear tags and equally (eight lambs per group) allocated in the four groups Indoor-Single Feeding (ISF), Outdoor-Single Feeding (OSF), Indoor-Cafeteria Feeding (ICF) and Outdoor Cafeteria Feeding (OCF) with similar live weights $(28.73,28.85,28.66$ and $28.85 \mathrm{~kg}$, $\mathrm{p}>0.05$ ). Each lamb within each group was one replicate and housed individually within $100 \times 120 \times 120 \mathrm{~cm}$ sized pen in both housing area.

Each individual pen contained two plastic buckets one for a single feed $(10 \mathrm{~L}$ capacity) and the other for water (15 L capacity). The pens of cafeteria animals contained seven plastic buckets ( $5 \mathrm{~L}$ capacity per bucket) for the main feed ingredients Barley (B), Corn (C), Wheat Bran (WB), Cotton Seed Meal (CSM), Full-Fat Soybean (FFS), Alfalfa straw (A) and water supply.

Control animals were fed $a d \mathrm{lib}$ a diet in mash form containing $168 \mathrm{~g}$ crude protein and $2517 \mathrm{kcal} \mathrm{ME} \mathrm{kg}^{-1}$ (Table 1) which was prepared from the above ingredients while cafeteria animals were allowed free access to the same ingredients with added vitamin and mineral mixture ( $2 \%$ of total ingredients).

At the beginning of the study, feed ingredients were offered to cafeteria animals in the same position from left to right (alfalfa straw, barley, corn, wheat bran, cotton seed meal and full-fat soybean) in plastic buckets for

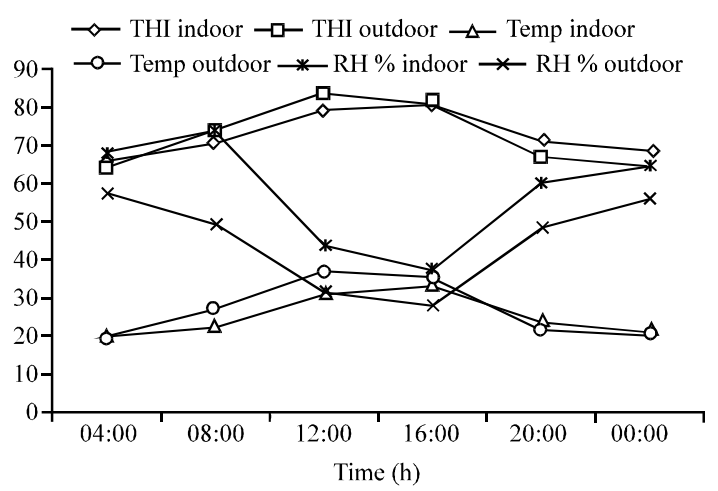

Fig. 1: Meteorological data

7 days to familiarize the metabolic consequences of feed ingredients. Feed and water intakes were determined daily (at 10:00) and lambs were weighed individually every fortnight.

The experiment lasted 42 days, from 31 August to 11 October 2007. The ambient temperature in pens were measured by using thermometer while humidity was measured by hygrometer once a week at the times 04:00, $08: 00,12: 00,16: 00,20: 00$ and $00: 00 \mathrm{~h}$ for 6 weeks. Temperature-Humidity Index (THI) (Tucker et al., 2008) was used as indicators of thermal comfort and calculated as follows:

$$
\mathrm{THI}=(1.8 \times \mathrm{T}+32)-((0.55-0.0055 \times \mathrm{RH}) \times(1.8 \times \mathrm{T}-26))
$$

Where:

$\mathrm{T}=$ Air temperature $\left({ }^{\circ} \mathrm{C}\right)$

$\mathrm{RH}=$ Relative Humidity $(\%)$

The climate conditions of experimental unit were $26.25^{\circ} \mathrm{C}$ average temperature with $50.60 \%$ humidity. The detailed information regarding meteorological data shown in Table 2 and Fig. 1.

Relative humidity was lower outdoor area than indoor area due to wind. THI is commonly used as an indicator of the degree of climatic stress on animals where a THI of 72 and below is considered as no heat stress, 73-77 as mild heat stress, $78-79$ as moderate and $>90$ as severe (Fuquay, 1981).

Each lamb was monitored behaviourally once a week for a period of $30 \mathrm{~min}$ at 10:00, 13:00, 16:00, 19:00, 22:00, 01:00, 04:00 and 07:00 h at $5 \mathrm{~min}$ intervals. After every $5 \mathrm{~min}$, each lamb was monitored to determine its activity. The first seen activity was recorded as the determined activity as explained by Keskin et al. (2004). The recorded activities were eating, drinking, ruminating, standing, lying and others. 
Table 2: Meteorological parameters of indoor and outdoor housing areas (mean $\pm \mathrm{SED}$ )

\begin{tabular}{|c|c|c|c|c|c|}
\hline \multirow[b]{2}{*}{$\underline{\text { Traits }}$} & \multirow[b]{2}{*}{ Hours } & \multicolumn{2}{|l|}{ Indoor } & \multicolumn{2}{|l|}{ Outdoor } \\
\hline & & Mean & Range & Mean & Range \\
\hline \multirow[t]{6}{*}{ Air temperature $\left({ }^{\circ} \mathrm{C}\right)$} & $04: 00$ & $20.00 \pm 1.92$ & $16-26.00$ & $18.80 \pm 2.27$ & $14-26$ \\
\hline & 08:00 & $22.25 \pm 3.49$ & $19-28.50$ & $26.85 \pm 1.54$ & $22-32$ \\
\hline & $12: 00$ & $31.15 \pm 0.95$ & $27-34.00$ & $36.43 \pm 2.15$ & $28-44$ \\
\hline & $16: 00$ & $32.83 \pm 0.70$ & $30-35.00$ & $35.17 \pm 0.65$ & $34-48$ \\
\hline & $20: 00$ & $23.60 \pm 0.98$ & $21-27.00$ & $21.40 \pm 1.63$ & $18-27$ \\
\hline & $00: 00$ & $21.40 \pm 1.54$ & $18-26.00$ & $19.68 \pm 2.00$ & $16-26$ \\
\hline \multirow[t]{6}{*}{ Relative humidity (\%) } & 04:00 & $67.80 \pm 9.85$ & $29-83.00$ & $57.00 \pm 9.26$ & $28-83$ \\
\hline & $08: 00$ & $73.33 \pm 2.17$ & $70-84.00$ & $49.17 \pm 3.33$ & $42-62$ \\
\hline & $12: 00$ & $43.33 \pm 3.52$ & $30-52.00$ & $31.67 \pm 2.70$ & $20-38$ \\
\hline & $16: 00$ & $37.17 \pm 5.22$ & $25-55.00$ & $27.50 \pm 1.12$ & $24-31$ \\
\hline & $20: 00$ & $60.00 \pm 8.69$ & $29-76.00$ & $48.40 \pm 8.62$ & $29-72$ \\
\hline & $00: 00$ & $64.60 \pm 9.18$ & $29-78.00$ & $55.60 \pm 9.87$ & $28-81$ \\
\hline \multirow[t]{6}{*}{ THI } & 04:00 & $65.60 \pm 2.84$ & $60-76.00$ & $63.60 \pm 3.01$ & $57-74$ \\
\hline & 08:00 & $70.00 \pm 2.10$ & $65-79.00$ & $74.17 \pm 2.04$ & $68-82$ \\
\hline & $12: 00$ & $78.83 \pm 1.27$ & $74-82.00$ & $82.83 \pm 2.80$ & $73-93$ \\
\hline & $16: 00$ & $79.67 \pm 0.56$ & $78-82.00$ & $80.50 \pm 0.85$ & $78-84$ \\
\hline & $20: 00$ & $70.60 \pm 1.70$ & $68-77.00$ & $66.60 \pm 1.96$ & $63-74$ \\
\hline & $00: 00$ & $67.80 \pm 2.15$ & $64-76.00$ & $64.40 \pm 2.64$ & $60-74$ \\
\hline
\end{tabular}

Additionally, Rectal Temperature (RT), Respiration Rate (RR) and Pulse Rate (PR) of lambs were determined at 07:00 am, 12:00 and 17:00 pm once a week. The rectal temperature was measured using digital thermometers (Omron MC-63, Omron Healthcare, Netherlands). Respiration rates were measured for $30^{\prime \prime}$ by counting thoracic and flank movements to detect clearly. Pulse rates were ascertained by use of a stethoscope through the ventral wall of the chest and also insertion time was $30 "$.

In this study, two factors (two housing and two feeding methods) were tested in factorial experimental design. Data concerning growth, feed intake, diet selection and physiological values were analysed using MANOVA (Windows Version of SPSS, release, 10.01). Behavioural data were subjected to $\chi^{2}$-test. Also the basal rate for single diet was compared as a pair by using one sample t-test in the same software. Means were ranked by using Duncan Multiple Range test.

\section{RESULTS AND DISCUSSION}

Table 3 shows that feed intake did not differ $(\mathrm{p}>0.05)$ between treatments. On the other hand, outdoor housing increase water intake, water/feed ratio, daily gain and feed efficiency while cafeteria feeding increased protein intake, energy intake and crude fibre intake $(\mathrm{p}<0.01)$. The higher rate of energy selection, protein selection and lower rate of fibre selection in outdoor cafeteria lambs indicated that outdoor cafeteria lambs preferred a high caloric and nitrogenous diet but less fibrous than other groups $(\mathrm{p}<0.01)$.

Figure 2 shows an insignificant difference in live weights between the experimental groups $(p>0.05)$. Single

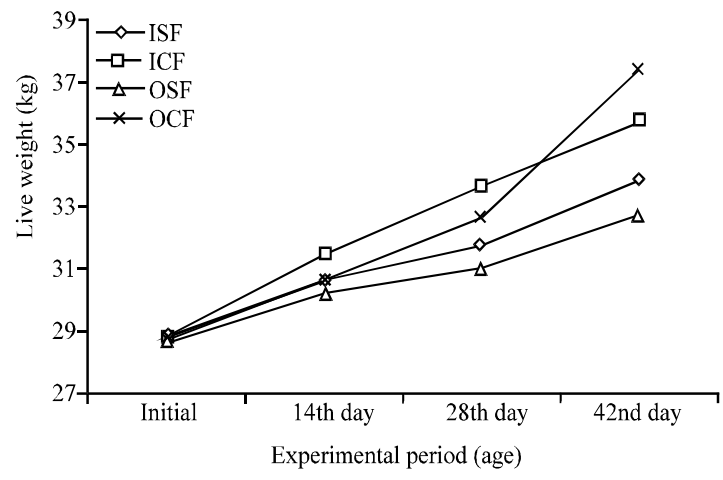

Fig. 2: Changes in live weight of experimental lambs

and cafeteria lambs kept in indoor and outdoor, reached $33.87,35.72,32.74$ and $37.37 \mathrm{~kg}$ live weight, respectively at the end of the experiment $(p>0.05)$. Outdoor cafeteria lambs tended to show better growth performance in comparison to other groups without statistical significance. Also there was difference between groups regarding daily gain during the experimental period $(p<0.01)$. The less daily gain was monitored in indoor cafeteria group and higher daily gain was observed in outdoor cafeteria group. Thus, the better FCR was obtained in outdoor cafeteria group.

The proportional intakes of feed ingredients by lambs are shown in (Table 4). Cafeteria lambs selected different level of feed ingredients than single diet depending on housing method. Indoor cafeteria lambs selected diet including $29.27 \% \mathrm{~B}, 27.10 \% \mathrm{C}, 11.63 \% \mathrm{CSM}, 3.30 \% \mathrm{FFS}$, $9.52 \% \mathrm{WB}$ and $19.17 \% \mathrm{~A}$ straw while outdoor cafeteria ones selected diet including $24.75 \% \mathrm{~B}, 27.12 \% \mathrm{C}, 9.60 \%$ CSM, $9.22 \% \mathrm{FFS}, 13.20 \% \mathrm{WB}$ and $16.12 \% \mathrm{~A}$ straw. The proportional dietary choices of FFS and WB was significantly higher in outdoor cafeteria lambs compared 
J. Anim. Vet. Adv., 10 (19): 2550-2556, 2011

Table 3: Daily food intake and performance traits of lambs

\begin{tabular}{|c|c|c|c|c|c|c|c|c|}
\hline \multirow{2}{*}{$\begin{array}{l}\text { Housing methods } \\
\text { Feeding methods }\end{array}$} & \multicolumn{2}{|l|}{ Indoor } & \multicolumn{2}{|l|}{ Outdoor } & \multirow[b]{2}{*}{ SEM } & \multicolumn{3}{|c|}{$p$-values } \\
\hline & Single & Cafeteria & Single & Cafeteria & & $\mathrm{HM}$ & FM & $\mathrm{HM} \times \mathrm{FM}$ \\
\hline Feed intake (g) & 1120.95 & 1248.95 & 1168.57 & 1253.45 & 25.13 & 0.801 & 0.067 & 0.873 \\
\hline Water intake (g) & 4045.11 & 4065.00 & 4415.53 & 4746.93 & 81.38 & 0.001 & 0.295 & 0.130 \\
\hline Water/feed ratio & 0003.61 & 3.29 & 3.77 & 3.82 & 0.06 & 0.009 & 0.315 & 0.169 \\
\hline Daily gain (g) & 0127.55 & 119.04 & 163.51 & 202.91 & 11.26 & 0.007 & 0.450 & 0.246 \\
\hline FCR & 0010.04 & 11.16 & 8.18 & 6.73 & 0.67 & 0.022 & 0.901 & 0.329 \\
\hline Protein intake (g) & 0188.32 & 235.40 & 196.32 & 241.89 & 6.48 & 0.631 & 0.000 & 0.880 \\
\hline ME intake (g) & 0002.82 & 3.19 & 2.94 & 3.26 & 0.06 & 0.630 & 0.022 & 0.931 \\
\hline CF intake (g) & 0101.24 & 114.73 & 105.54 & 111.42 & 2.33 & 0.915 & 0.046 & 0.416 \\
\hline Protein selection & 0168.00 & $189.22^{* * *}$ & 168.00 & $192.44^{* * *}$ & 2.56 & - & - & - \\
\hline ME selection & 0002.52 & $2.55^{* * *}$ & 2.52 & $2.60^{* * *}$ & 0.01 & - & - & - \\
\hline CF selection & 0090.32 & $92.34^{* * *}$ & 90.32 & $88.57^{* * * *}$ & 0.75 & - & - & - \\
\hline
\end{tabular}

Table 4: The proportional content of feed ingredients in single diet or diets made by lambs subjected to indoor and outdoor housing (mean \pm SED (\%))

\begin{tabular}{|c|c|c|c|c|}
\hline \multirow{2}{*}{$\begin{array}{l}\text { Feeding methods } \\
\text { Housing methods }\end{array}$} & \multirow{2}{*}{$\begin{array}{l}\text { Single feeding } \\
\text { (Man-made diet) }\end{array}$} & \multicolumn{2}{|c|}{ Cafeteria feeding (Lambs-made diet) } & \multirow[b]{2}{*}{$\mathrm{p}$-value } \\
\hline & & Indoor & Outdoor & \\
\hline \multicolumn{5}{|l|}{ Feed ingredients/diets } \\
\hline Barley (B) & 40 & $29.27 \pm 1.82^{*}$ & $24.75 \pm 2.43^{*}$ & 0.32 \\
\hline Corn (C) & 5 & $27.10 \pm 2.08^{*}$ & $27.12 \pm 2.13^{*}$ & 0.95 \\
\hline Cotton Seed Meal (CSM) & 9 & $11.63 \pm 0.92^{*}$ & $9.60 \pm 1.92 *$ & 0.42 \\
\hline Full-Fat Soybean (FFS) & 9 & $3.30 \pm 0.85^{*}$ & $9.22 \pm 0.82 *$ & 0.00 \\
\hline Wheat Bran (WB) & 25 & $9.52 \pm 1.02^{*}$ & $13.20 \pm 1.11^{*}$ & 0.01 \\
\hline Alfalfa hay (A) & 10 & $19.17 \pm 1.40^{*}$ & $16.12 \pm 1.86^{*}$ & 0.25 \\
\hline
\end{tabular}

aShows the significance in differences between the diets selected by the lambs; "Denotes the difference between the diets selected by lambs and single diet based on one sample t-test $(\mathrm{p}<0.05)$

Table 5: The proportional count of behavioural elements in accordance with the pooled observations (mean (\%))

\begin{tabular}{|c|c|c|c|c|c|}
\hline Treatments/behavioural elements & Indoor single feeding & Outdoor single feeding & Indoor cafeteria feeding & Outdoor cafeteria feeding & $p$-value $e^{a}$ \\
\hline Eating & 19.21 & 19.97 & 18.02 & 18.75 & 0.454 \\
\hline Drinking & 1.40 & 1.04 & 1.43 & 1.25 & 0.675 \\
\hline Ruminating & 11.96 & 6.65 & 11.25 & 11.28 & 0.000 \\
\hline Lying & 24.18 & 32.76 & 28.47 & 28.08 & 0.000 \\
\hline Standing & 40.57 & 37.45 & 38.45 & 37.06 & 0.880 \\
\hline Others & 2.68 & 2.13 & 2.38 & 3.58 & 0.001 \\
\hline Total scans in percentage & 100.00 & 100.00 & 100.00 & 100.00 & - \\
\hline
\end{tabular}

${ }^{\text {a }}$ Shows statistical significance between treatments

to indoor ones ( $\mathrm{p}=0.00$ and 0.01 , respectively). Table 5 and Fig. 3a-c shows the percentage count of eating, ruminating, standing and lying behaviour of lambs on time basis in a day. Table 5 shows that lambs showed similar eating, drinking, standing behaviours irrespective to treatments. Eating were 19.21, 19.97, 18.02 and $18.75 \%$ ( $>0.05)$, drinking were $1.40,1.04,1.43$ and $1.25 \%(\mathrm{p}>0.05)$, ruminating were $11.96,6.65,11.25$ and $11.28 \%$ ( $<<0.001)$, lying were $24.18,32.76,28.47$ and $28.08 \%(\mathrm{p}<0.001)$, standing were $40.57,37.45,38.45$ and $37.06 \%(\mathrm{p}>0.05)$ respective groups ISF, $\mathrm{OSF}, \mathrm{ICF}$ and $\mathrm{OCF}$.

Single fed lambs when kept outdoor showed lower ruminating activity than those of indoors but showed the more lying behaviour $(\mathrm{p}<0.01)$. Figure 3a-c shows that the time dependent ruminating, drinking and lying behaviours of experimental animals. Single fed indoor lambs showed more ruminating behaviour in early morning. Drinking behaviour was not affected by treatment except at 16:00 in outdoor cafeteria fed lambs. These lambs showed more drinking activity than other treatment groups. Outdoor single fed animals showed more lying behaviour during the period of 13:00-16:00 h.

This study was conducted to investigate the relationship between the housing condition and cafeteria feeding with respect to growth performance, diet selection and physiological status. Outdoor cafeteria lambs tended to show better growth performance in comparison to other groups without statistical significance. Also the better FCR was obtained in outdoor cafeteria group. It might be explained by:

- Water intake

- Air circulation

- Dietary self selection

Outdoor housing increased water intake. Sheep consume less water per unit of dry matter intake than cattle but the intake increases with an increase in ambient temperature. Sheep consume $2 \mathrm{~kg}$ water $/ \mathrm{kg} \mathrm{DM}$ at temperatures between 0 and $15^{\circ} \mathrm{C}$. This ratio increases to 

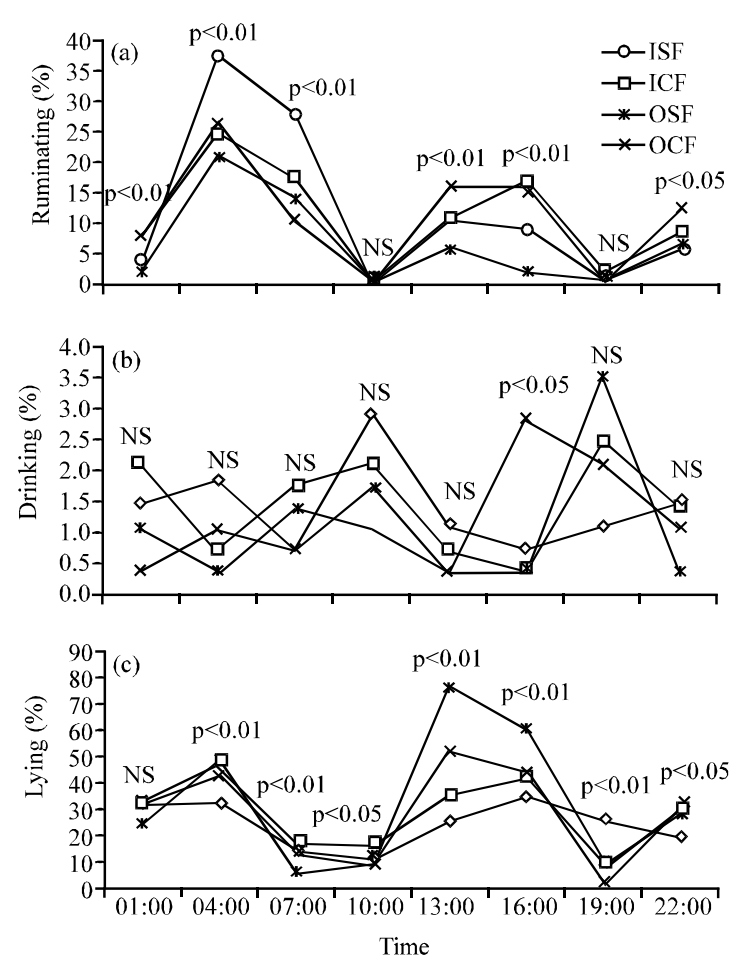

Fig. 3a-c: Ruminating, drinking and lying behaviour of experimental lambs

3:1 at temperatures above $20^{\circ} \mathrm{C}$ (Conrad, 1985). As shown in Table 5, all animals consume water at above 3:1 water: food ratio. Water intake was significantly higher at 11:00-15:00 and 15:00-19:00 than 7:00-11:00 and in the summer than during winter (Marai et al., 1997, 2000). In the present study, outdoor cafeteria lambs showed more drinking behaviour at 19:00 while indoor single fed lambs showed more drinking behaviour than the other group of lambs. In the present study, indoor housing subjected lambs more heat stress due to lack of air circulation than outdoor ones. Outdoor cafeteria lambs showed drinking behaviour about 20 times more than indoor ones at 16:00.

The air circulation and consuming the high proportion of full fat soya and wheat bran may cause the higher rate of drinking. Outdoor cafeteria lambs chose less barley and alfalfa hay and more full fat soya and wheat bran compared to indoor cafeteria lambs. This might be explained that outdoor lambs tried to reduce body heat by consuming concentrate feed which was not cause fermentative heat in their rumen.

Indoor lambs showed higher incidence of eating behaviour rather than that of the other groups. Feed refreshing was at 10:00 during the experiment period. Therefore, refreshing feed increased eating activity at that time in lambs $(\mathrm{p}<0.01)$. As reported previously studies, eating activity were higher in early morning (at 07:00) and late evening time (19:00). Generally, sheep tend to forage very early in the morning and again late in the evening with periods of grazing, resting and rumination during the day (Sutherland, 1967). They do not eat in the hottest part of the day (Johnson, 1987). Indoor animals ruminated more than outdoor ones since their diet contained more fibrous ingredients. Outdoor lambs either in single and cafeteria fed did not stand up as much as indoor ones. They do not need to stand up due to wind at outsite of barn. Indoor lambs had to stand up in order to help in dissipating body heat since THI was high as a result of lack of wind indoor housing condition. Heat lost by the skin dependent partly on the temperature gradient between skin and air and solid objects. Air velocity is one of the important factors influencing evaporative heat transfer. Ittner et al. (1951) reported that the reduced skin and body temperatures were obtained by increasing the air velocities over pigs and cattle subjected to high ambient temperatures.

Outdoor lambs were usually lying down on the floor at 13:00 and 16:00 h. They did not need to stand up to dissipate body heat due to air circulation in outdoor. Outdoor cafeteria lambs preferred lower fibrous feed ingredients. Highly fibrous material, release much heat during the process of fermentation. This heat increment exacerbates the heat load of the animal by increasing the internal heat load (Beede and Collier, 1986; Goetsch and Johnson, 1999; West, 1999). Adding fat to the diet increases energy density and lowers total heat increment thereby reducing body heat load (Beede and Shearer, 1991). Outdoor lambs increased to consume high fat contained feed ingredients full fat soya and corn when given to them a choice but decreased barley and wheat bran.

According to Table 6, outdoor or indoor lambs tuned their body heat by dietary arrangement, pulse rate and respiration rate. The $\mathrm{RT}$ was markedly lower at $08: 00$ than at 12:00 and 16:00. The RR was higher in outdoor lambs than indoor ones $(\mathrm{p}<0.01)$. The RR can be an indicator of heat stress (Habeeb et al., 1992). Sheep loose approximately $20 \%$ of total body heat via respiratory moisture in a neutral environmental temperature $\left(12^{\circ} \mathrm{C}\right)$. With regard to the effect of humidity when a load of high relative humidity was superimposed upon as already high ambient temperature, there was a further increase in respiratory frequency in sheep. This was related to an increase in the perception of warmth (Marai et al., 2002). The PR reflects primarily the homeostasis of circulation along with the general physiologic status. The rate increases on exposure to high environmental temperature (Aboul-Naga, 1987). 
Table 6: The differences of rectal temperature $\left(\mathrm{RT},{ }^{\circ} \mathrm{C}\right)$, respiration $\left(\mathrm{RR}\right.$, breath $\left.\mathrm{min}^{-1}\right)$ and pulse rate $\left(\mathrm{PR}\right.$, beat $\left.\mathrm{min}^{-1}\right)$ of groups in a day

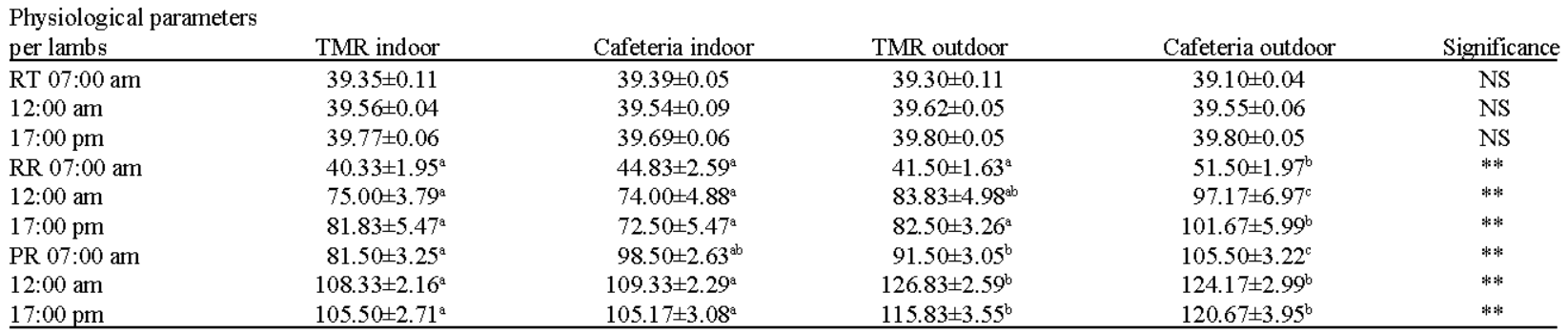

${ }_{* * *}^{*}<0.01$, NS: Not Significant; ${ }^{a-c}$ : Values marked with different letters in line are significantly different

As the ambient temperature increases, the PR as well as the circulation of blood increase to transfer from the core to the periphery. During the day, the PR was significantly higher in outdoor lambs compared to indoor lambs. Earlier work with Awassi lambs (Bhattacharya and Hussain, 1974) found that RR, PR and RT significantly increased at high temperatures and that the effect was most pronounced when lambs were consuming diets consisting of a high proportion of roughage. However, in the present study, cafeteria feeding allowed lambs to arrange their physiological status by dietary self selection.

\section{CONCLUSION}

In the study, single fed Awassi lambs kept in outdoor in hot climate showed less ruminating but more lying behaviour while given opportunity to choose a diet they ate more concentrate feed ingredients such as full fat soya and wheat bran without changing their behaviour patterns. Cafeteria feeding in lambs allows physiological arrangements against heat stress in outdoor housing condition by dietary self selection and by tuning respiratory and circulatory systems.

\section{ACKNOWLEDGEMENTS}

This research was supported by Mustafa Kemal University Research Foundation (Project No: 08 B 0302). The researcher would like to thank Dr. Ahmet SAHIN and Dr. Sabri GUL for their helps as expert in their fields.

\section{REFERENCES}

Abdel-Samee, A.M. and J.R. Diel, 1998. Shearing and fat supplementation effects on growth traits of Suffolk lambs under moderate and severe heat stress conditions. Proceedings of the 1st International Conference on Animal Production and Health in Semi-Arid Areas, Sept. 1-3, Faculty of Agricultural Sciences, Suez Canal University: El Arish, Egypt, pp: $251-259$.
Aboul-Naga, A.I., 1987. The role of aldosterone in improving productivity of heat-stressed farm animals with different techniques. Ph.D. Thesis, Faculty of Agriculture, Zagazig University, Zagazig, Egypt.

Arsenos, G. and I. Kyriazakis, 1999. The continuum between preferences and aversions for flavoured foods in sheep conditioned by administration of casein doses. Anim. Sci., 68: 605-616.

Beatty, D.T., A. Barnes, E. Taylor, D. Pethick, M. McCarthy and S.K. Maloney, 2006. Physiological responses of Bos taurus and Bos indicus cattle to prolonged continuous heat and humidity. J. Anim. Sci., 84: 972-985.

Beede, D.K. and J.K. Shearer, 1991. Nutritional management of dairy cattle during hot weather. Agric. Pract., 12: 5-13.

Beede, D.K. and R.J. Collier, 1986. Potential nutritional strategies for intensively managed cattle during thermal stress. J. Anim. Sci., 62: 543-554.

Bhattacharya, A.N. and F. Hussain, 1974. Intake and utilization of nutrients in sheep fed different levels of roughage under heat stress. J. Anim. Sci., 38: 877-886.

Bianca, W., 1962. Relative importance of dry and wet bulb temperature in causing heat stres in cattle. Nature, 195: 251-252.

Brink, D.R., 1975. Effect of ambient temperature on lamb performance. M.Sc. Thesis, Kansas State University, United States of America.

Conrad, J.H., 1985. Feeding of farm animals in hot and cold environments. In: Stress Physiology in Livestock, Yousef, M.K. (Ed.). CRC Press Inc., Boca Raton, Florida, USA.

Dixon, R.M., R. Thomas and J.H.G. Holmes, 1999. Interactions between heat stress and nutrition in sheep fed roughage diets. J. Agric. Sci., 132: 351-359.

Finch, V.A., 1984. Heat as a Stres Factor in Herbivores Under Tropical Conditions. In: Herbivore Nutrition in the Subtropics and Tropics, Gilchrist, F.M.C. and R.I. Mackie (Eds.). The Science Press, Craighall, South Africa, pp: 89-105. 
Forbes, J.M., 1995. Voluntary Food Intake and Diet Selection in Farm Animals. CABI Publishing, UK., ISBN-10: 085198908X, pp: 544.

Fuquay, J.W., 1981. Heat stress as it affects animal production. J. Anim. Sci., 52: 164-174.

Goetsch, A.L. and Z.B. Johnson, 1999. Feed intake and digestion in the summer and fall by different breeds of ewes consuming forages differing in quality. Small Rumin. Res., 31: 109-116.

Gorgulu, M., H.R. Kutlu, E. Demir, O. Ozturkcan and J.M. Forbes, 1996. Nutritional consequences amoung ingredients of free-choice feeding Awassi lambs. Small Rumin. Res., 20: 23-29.

Habeeb, A.A.M., I.F.M. Marai and T.H. Kamal, 1992. Heat Stress. In: Farm Animals and the Environment, Philips, C. and D. Piggens (Eds.). CAB. International, Wallingford, UK., pp: 27-47.

Hayes, B.J., M. Carrick, P. Bowman and M.E. Goddard, 2003. Genotype $\mathrm{x}$ environment interaction for milk production of daughters of australian dairy sires from test-day records. J. Dairy Sci., 86: 3736-3744.

Holst, P.J. and D.F. Stanley, 2000. Shade and trough water temperature for lambs. Asian Australas. J. Anim. Sci., 13: $147-147$.

Ittner, N.R., C.F. Kelly and H.R. Guilbert, 1951. Water consumption of hereford and brahman cattle and the effect of cooled drinking water in a hot climate. J. Anim. Sci., 10: 742-751.

Johnson, H.D., 1987. Bioclimatology and the Adaptation of Livestock. Elsevier Science, Publishers BV5, Amesterdam, Oxford, New York, Tokyo.

Keskin, M., A. Sahin, O. Bicer and S. Gul, 2004. Comparison of the behaviour of Awassi lambs in cafeteria feeding system with single diet feeding system. Applied Anim. Behav. Sci., 85: 57-64.

Kyriazakis, I. and J.D. Oldham, 1993. Diet selection in sheep: The ability of growing lambs to select a diet that meets their crude protein (nitrogen * 6.25) requirements. Br. J. Nutr., 69: 617-629.

Marai, I.F.M., A.A.M. Habeeb and A.E. Gad, 2002. Reproductive traits of female rabbits as affected by heat stress and light regime, under sub-tropical conditions of Egypt. J. Anim. Sci., 75: 451-458.
Marai, I.F.M., L.B. Bahgat, T.H. Shalaby, M.A. AbdelHafez, 2000. Fattening performance, some behavioural traits and physiological reactions of male lambs fed concentrates mixture alone with or without natural clay, under hot summer of Egypt. Ann. Arid Zone, 39: 449-460.

Marai, I.F.M., T.H. Shalaby, L.B. Bahgat and M.A. Abdel-Hafez, 1997. Fattening of lambs on concentrates mixture diet alone without roughages or with addition of natural clay under subtopical conditions of Egypt. Physiological reactions. Proceedings of International Conference on Animal Production and Health, Dakki, Cairo, Egypt.

McDowell, R.E., 1972. Improvement of Livestock Production in Warm Wet Climate. W.H. Freeman and Company, San Francisco, USA., pp: 22.

Rose, S.P. and I. Kyriazakis, 1991. Diet selection of pigs and poultry. Proc. Nutr. Soc., 50: 87-98.

Sahin, A., H. Yildirim, S. Kaya, S. Canogullari and M. Baylan, 2001. Selection of whole wheat by broiler chickens in semi-commercial experimental conditions. Hayvansal Uretim, 42: 8-20.

Sahin, A., M. Keskin, O. Bicer and S. Gul, 2003. Diet selection by Awassi lambs fed individually in a cafeteria feeding system. Livest. Prod. Sci., 82: 163-170.

Silanikove, N., 1992. Effects of water scarcity and hot environment on appetite and digestion in ruminants: A review. Livest. Prod. Sci., 30: 175-194.

Silanikove, N., 2000. Effects of heat stres on the welfare of extensively managed domestic ruminants. Livest. Prod. Sci., 67: 1-18.

Sutherland, J.A., 1967. Understanding Farm Animals. Angus and Robertson Ltd., Sidney, Australia, pp: 233.

Thwaites, C.J., 1967. Fleece lenght and the reactions of sheep to elevated humidity and radiant heating at high ambient temperatures. Res. Vet. Sci., 8: 463-466.

Tucker, C.B., A.R. Rogers and K.E. Schutz, 2008. Effect of solar radiation on dairy cattle behaviour, use of shade and body temperature in a pasture-based system. Applied Anim. Behav. Sci., 109: 141-154.

West, J.W., 1999. Nutritional strategies for managing the heat stressed dairy cow. J. Anim. Sci., 77: 21-35. 